\title{
Optimal Solutions for the Use of Sewage Sludge on Agricultural Lands
}

\author{
Catalina Iticescu ${ }^{1}$ (), Puiu-Lucian Georgescu ${ }^{1}$, Maxim Arseni ${ }^{1}{ }^{\circledR}$, Adrian Rosu ${ }^{1}$, Mihaela Timofti ${ }^{1}$, Gabriel Carp ${ }^{1}$ \\ and Lucian-Ionel Cioca ${ }^{2,3, *(\mathbb{D})}$ \\ 1 European Center of Excellence for the Environment, Faculty of Sciences and Environment, "Dunaărea de Jos" \\ University of Galati, 111 Domneasca Street, 800201 Galati, Romania; catalina.iticescu@ugal.ro (C.I.); \\ lucian.georgescu@ugal.ro (P.-L.G.); maxim.arseni@ugal.ro (M.A.); adrian.rosu@ugal.ro (A.R.); \\ mihaela.timofti@ugal.ro (M.T.); gabriel.carp@ugal.ro (G.C.) \\ 2 Industrial Engineering and Management Department Emil Cioran, Faculty of Engineering, Lucian Blaga \\ University of Sibiu, Street, no. 4, 550025 Sibiu, Romania \\ 3 Academy of Romanian Scientists, 3 Ilfov Street, Sector 5, 010071 Bucharest, Romania \\ * Correspondence: lucian.cioca@ulbsibiu.ro
}

Citation: Iticescu, C.; Georgescu, P.-L.; Arseni, M.; Rosu, A.; Timofti, M.; Carp, G.; Cioca, L.-I. Optimal Solutions for the Use of Sewage Sludge on Agricultural Lands. Water 2021, 13, 585. https://doi.org/ 10.3390/w13050585

Academic Editor: Maria Cristina Collivignarelli

Received: 24 December 2020

Accepted: 19 February 2021

Published: 24 February 2021

Publisher's Note: MDPI stays neutral with regard to jurisdictional claims in published maps and institutional affiliations.

Copyright: (C) 2021 by the authors Licensee MDPI, Basel, Switzerland. This article is an open access article distributed under the terms and conditions of the Creative Commons Attribution (CC BY) license (https:/ / creativecommons.org/licenses/by/ $4.0 /)$.

\begin{abstract}
The use of sewage sludge in agriculture decreases the pressure on landfills. In Romania, massive investments have been made in wastewater treatment stations, which have resulted in the accumulation of important quantities of sewage sludge. The presence of these sewage sludges coincides with large areas of degraded agricultural land. The aim of the present article is to identify the best technological combinations meant to solve these problems simultaneously. Adapting the quality and parameters of the sludge to the specificity of the land solves the possible compatibility problems, thus reducing the impact on the environment. The physico-chemical characteristics of the fermented sludge were monitored and optimal solutions for their treatment were suggested so as to allow that the sludge could be used in agriculture according to the characteristics of the soils. The content of heavy metals in the sewage sludge was closely monitored because the use of sewage sludge as a fertilizer does not allow for any increases in the concentrations of these in soils. The article identifies those agricultural areas which are suitable for the use of sludge, as well as ways of correcting some parameters (e.g., pH), which allow the improvement of soil quality and obtained higher agricultural production.
\end{abstract}

Keywords: sewage sludge; physico-chemical parameters; mapping; soil amendment; heavy metals

\section{Introduction}

In order to meet the requirements of the European Union, significant investments have been made in Romania in recent years so as to extend, modernize, and build municipal waste water treatment plants [1].

The problems originating in the waste waters are solved in compliance with the corresponding EU legislation in force. The main legislative regulation is the Water Framework Directive [2], which establishes the policy framework for water management in the European Union, based on the principles of sustainable development and integrates all water related problems.

The main objective of the Water Framework Directive (WFD) is to achieve good ecological status for all bodies of water, both surface and underground, except for the heavily modified and artificial bodies of water for which the "good environmental potential" is defined.

According to the requirements of Directive 91/271/EEC [3] regarding the treatment of urban waste water which may contain domestic wastewater or mixtures of domestic, industrial and meteoric waters, this type of water is collected by using sewage systems, directed to the wastewater treatment plant (where they are properly treated) and then it is discharged into the surface water, taking into account the maximum acceptable concentrations. 
As a result of the purging process, large amounts of sewage sludge result. The sludge from municipal waste water treatment plants is generated in different stages of the wastewater treatment. They contain both compounds with agrochemical value (organic matter, nitrogen, phosphorus, potassium, and small amounts of calcium, sulfur, magnesium) and pollutants, such as heavy metals, toxic organic substances and pathogens. The characteristics of the sludge depend on the degree of pollution, on the nature of the pollutants in the treated wastewater and on the sludge treatment methods [4-8].

In order to treat and use the sludge obtained in a wastewater installation, it is very important that its parameters should be known. Several important parameters are usually monitored: $\mathrm{pH}$, alkalinity, and organic acid content. Moreover, the content of heavy metals, pesticides and hydrocarbons must be determined when the sludge is to be used in agriculture, to be incinerated or to be stored [9-16].

Since there are large quantities of sludge from sewage treatment plants, the issue of choosing an optimal disposal method is of utmost importance. The disposal methods must be chosen taking into account several aspects: the environmental impact (including human health), economic costs, public perception problems (especially the smell of these sludges, etc.) $[12,17-20]$. One of the valid solutions is the use of sludges in agriculture which implies a series of advantages among which natural nutrient intake, soil texture improvement and even water intake, if sludge distribution is performed before its drying. A particularly delicate aspect is that sludges contain, in addition to various beneficial substances, heavy metals, microorganisms, viruses or other pathogens which represent a potential hazard to human and animal health and to the quality of ecosystems, in case they are used as a fertilizer [21-30].

Elimination/reduction of sewage sludge can also be achieved by incineration in cement factories, thermal plants, blast furnaces, or by storage in waste household $[1,5,8,12,18,31]$. The management of sewage sludge is achieved by complying with the National Waste Management Strategy 2014-2020 (HG 870/2013) and the National Waste Management Plan (H.G. no. 1470/09.09.2004) [32,33]. These are the main documents taken into consideration for implementing the European Union policies on Waste Management in Romania.

The method of administration on agricultural lands in agriculture is much more advantageous from an economic point of view than the other methods. In addition to the economic advantages, higher agricultural products are obtained due to the intake of nutrients from the sewage sludge. When using sewage sludge, the fact must be taken into account that only certain types of plants can be grown on the respective lands. The most widely spread crops are preferably wheat, corn, and sunflower. Additionally, a multitude of other conditions must be taken into consideration such as: slope, type of crop, harvest period, etc. [34-37].

One of the problems which may appear after the administration of the sludge on agricultural lands, is the modification of their physico-chemical parameters. These changes in parameters are a natural consequence of the chemical and biochemical reactions which occur by the nature of the constituents of sludge and soil. In addition to the beneficial effects of organic substances contained in sewage sludge, which bring a substantial intake of nitrogen and organic phosphorus, sewage sludge may change, over time, the pH of soils due to the biochemical reactions occurring as a result of its interactions with soil bacteria, which lead to the formation of organic acids. It also increases the content of heavy metals. For this reason, the physico-chemical parameters of the sludge need to be monitored very carefully $[10,11,14,18,21,25,31,34]$.

The use of sewage sludge in agriculture decreases the pressure on landfills. In Romania, massive investments have been made in wastewater treatment stations in recent years, which have resulted in the accumulation of very important quantities of sewage sludge. In the southeast (SE) Region of Romania, the presence of these sewage sludges coincides with large areas of degraded agricultural land. The aim of the present article is to identify the best technological combinations meant to solve these problems simultaneously, thus 
reducing the pressure on the environment by means of long-term, sustainable solutions that may be reliable from an economic point of view, as well.

The sewage sludge to be applied on agricultural lands in Galati County were analyzed in the present paper. The content of heavy metals in the sewage sludge was closely monitored bearing in mind the fact that the legislation in the field is very strict and the use of sewage sludge as a fertilizer does not allow for any increases in the concentrations of heavy metals in soils. The sewage sludge was treated with calcium amendments after undergoing the anaerobic digestion process, thus avoiding the $\mathrm{pH}$ decrease in the agricultural soils on which they were applied. An assessment was also made regarding the content of heavy metals in the soils intended for agriculture.

\section{Materials and Methods}

\subsection{Characterization of Sewage Sludge}

The characterization of sewage sludge and agricultural soils in terms of their physicalchemical properties was made by using various methods. The sewage sludge applied on the lands was collected from the Wastewater Treatment Station (WWTS) in Galati, Romania and the study was conducted during the years 2017-2018. Sewage sludge is applied on agricultural land twice a year, leaving an interval of at least six months between the two applications. The sludge deposited on agricultural land is strictly monitored in terms of heavy metal content: chromium, copper, nickel, lead, zinc, cadmium, and mercury [2,38]. Determinations of nutrient and heavy metal content were made between February-March 2017; September-October 2017; February-March 2018; August-September 2018. Sludge and soil samples were taken observing the regulations in force [39-55]. The sludge samples were taken before entering the digester (sets 1-4, undigested sludge) and after the anaerobic digestion (sets 5-8, digested sludge). WWTS Galati produces 3200 tons of sludge/year, and these can be applied on the studied agricultural lands.

The physico-chemical parameters relevant for the qualities required when applying sewage sludge as a fertilizer on agricultural land were determined (Table 1).

Table 1. Methods of sewage sludge and agricultural soils analysis [38-45].

\begin{tabular}{cc}
\hline Parameter & Method/Standard \\
\hline $\mathrm{pH}$ & SR EN 12176 \\
\hline $\mathrm{N}$-total & SR ISO 11261:2000 \\
\hline $\mathrm{NH}_{4}{ }^{+}$ & SR ISO 14255:2000 \\
\hline $\mathrm{P}$-total & SR ISO 11261:2000 \\
\hline $\mathrm{Cr}$-total & SR EN 16192:2012 \\
\hline $\mathrm{Cu}^{2+}$ & SR 13179/93 \\
\hline $\mathrm{Ni}^{2+}$ & SR EN 16192:2012 \\
\hline
\end{tabular}

The physico-chemical parameters determined for sewage sludge and soils were: $\mathrm{pH}(\mathrm{upH}), \mathrm{N}_{\text {tot }}\left(\mathrm{mg} \cdot \mathrm{L}^{-1}\right), \mathrm{NH}^{4+}-\mathrm{N}\left(\mathrm{mg} \cdot \mathrm{L}^{-1}\right), \mathrm{P}_{-}$total $\left(\mathrm{mg} \cdot \mathrm{L}^{-1}\right)$ and content of heavy metals: $\mathrm{Cr}_{\text {tot }}\left(\mathrm{mg} \cdot \mathrm{kg}^{-1}\right.$ s.u. $), \mathrm{Cu}^{2+}\left(\mathrm{mg} \cdot \mathrm{kg}^{-1}\right.$ s.u. $), \mathrm{Ni}^{2+}\left(\mathrm{mg} \cdot \mathrm{kg}^{-1}\right.$ s.u. [39-55]. The chemical composition of the sludge samples was determined by using eEnergy-dispersive $\mathrm{X}$-ray spectroscopy (EDX) methods, as well as atomic absorbtion spectroscopy (AAS) from $\mathrm{Cu}$, electrometric, and spectrophotometric methods. All the samples were processed according to the regulations in force [38].

The sewage sludge was treated with a mixture of calcite and dolomite so as to raise its $\mathrm{pH}$ and to avoid a decrease of the $\mathrm{pH}$ of the amended agricultural soils.

\subsection{Characteristics of the Analyzed Soils}

In order to establish the quality of the agricultural lands, pedological and agrochemical tests were performed. The agrochemical samples consisted of average soil samples which 
were collected from depths of 20-25 cm, and the collection area for each average sample was 5 ha. The following parameters were determined in the soil samples: $\mathrm{pH}$ reaction analysis (by potentiometric method), soil texture (particle size methods), bulk density, humus content, nitrogen index, $\mathrm{C}: \mathrm{N}$ ratio, total nitrogen, mobile phosphorus content, mobile potassium, exchange bases (determination of cation exchange properties), and the degree of saturation in bases (Table 2).

Table 2. Methods of analysis of characteristics of agricultural soils [46-56].

\begin{tabular}{cc}
\hline Parameter & Method/Standard \\
\hline Texture & \\
\hline Dense sand $(2.0-0.02 \mathrm{~mm})$ & \\
\hline Fine sand $(0.2-0.02 \mathrm{~mm})$ & STAS 7184/10-79 \\
\hline Dust $(0.002-0.02 \mathrm{~mm})$ & \\
\hline Argil $(<0.002 \mathrm{~mm})$ & \\
\hline Apparent density $\left(\mathrm{g} \cdot \mathrm{cm}^{-3}\right)$ & ISO 11272:1998 \\
\hline pH & SR 7184-13:2001 \\
\hline Humus & STAS 7184-21-82 \\
\hline Nitrogen index $(\mathrm{IN})$ & Kjeldhal method \\
\hline C:N & Scheibler method \\
\hline $\mathrm{N}_{\text {total }}$ & STAS 7184/2-85 \\
\hline P $_{\text {mobil }}(\mathrm{ppm})$ & STAS 7184/19-82 \\
\hline $\mathrm{K}_{\text {mobil }}(\mathrm{ppm})$ & Egner-Riehm-Domingo method \\
\hline Exchange bases (EB) & SR ISO 13536:2001 \\
\hline Hydrolytic acidity (HA) & SR EN ISO 11260:2018 \\
\hline Degree of saturation in bases (Vah) & SR EN 16502:2015 \\
\hline
\end{tabular}

The quantities of sludge were distributed on the surfaces of the agricultural lands by the local sewage sludge producer (WWTP-Galati) using specific agricultural mechanical spreading equipments. The distribution was made twice a year, once every six months, in specific periods when there were no crops on the respective lands.

\subsection{Statistical Analyses}

Statistical studies were performed by applying the principal component analysis (PCA). PCA is the most used statistical procedure which allows reducing the original multidimensional space in a lower-dimensional space without losing data signification. By summarizing the information content, the lower-dimensional space of data can be easily visualized and analyzed. This type of statistical procedure, namely PCA, was first defined and mentioned by Hotelling in 1933 [57] and it may be applied in different areas by researchers. Doyi [58] used the PCA analysis to assess the correlation between spatial distribution, accumulation, and human health risk assessment of heavy metals in soil and groundwater of the Tano Basin, Ghana. The PCA analysis output pointed to the anthropogenic origin of $\mathrm{Pb}$ and $\mathrm{Cd}$ in the Tano Basin and in the surrounding communities.

First of all, the data of the parametric statistical set was normalized and then it was checked if the normally distributed data corresponded to a population with a normal distribution. In this case, the normal distribution was verified by applying the Shapiro-Wilk's test with a significance level $=0.05$. The non-normal data were transformed logarithmically to achieve a normal distribution. Additionally, Pearson's statistics were applied to the data. The Pearson's correlation allows to analyze the relationships, or to measure the association between the two variables of interest. In the present research, this type of statistical analysis 
provided information about the correlation between physico-chemical parameters, and the direction of the relationship.

The advantage of the PCA method is given by the possibility to explain the variance in the data while reducing the number of variables to several groups of individuals [59]. The processes of PCA analysis were applied in this paper in order to identify various groups of correlated physico-chemical soil parameters and those which can be considered as having a similar common origin or behaviour [60].

\section{Results}

The use of sewage sludge in agriculture must be necessarily associated with a permanent monitoring of the physical, chemical and biological characteristics of the sludge, as well as with a permanent monitoring of its impact on the quality of the amended agricultural land.

The levels of heavy metals of sewage sludge were determined by using the AAS, XRF, and spectrophotometric methods. It has been found that the level of heavy metals in all the analyzed samples is lower than the maximum values specified by the legislation in force (Directive 86/278/EEC).

The elemental sludge composition was determined by using the EDX method (Figure 1). It has been found that it contains significant quantities of organic substances, the carbon content being high. It has also been found that there is a significant amount of oxides, the oxygen content being relatively high. The content of metals is relatively low and nutrient-specific elements $(\mathrm{N}, \mathrm{P}, \mathrm{K})$ are also present.

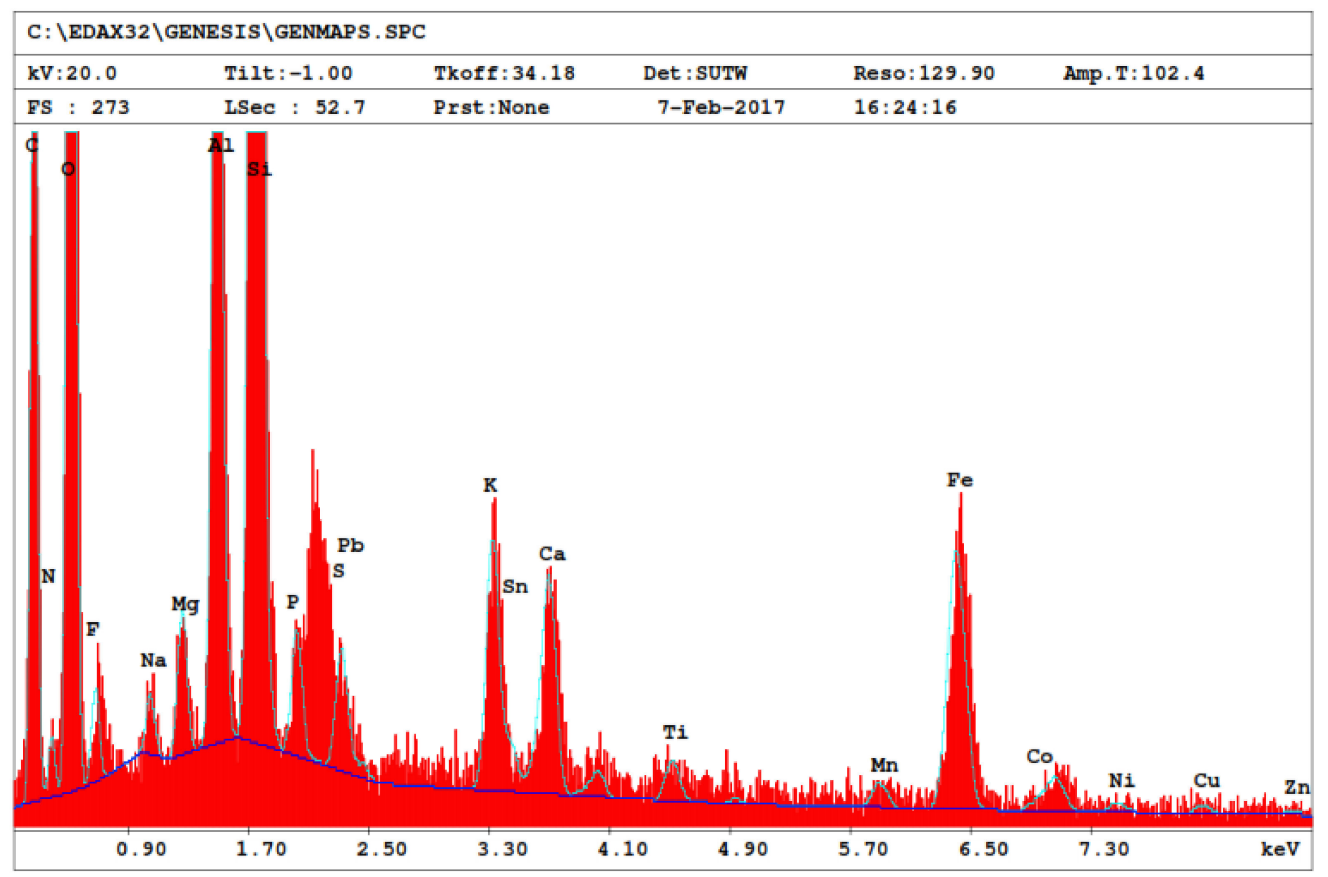

Figure 1. Elemental composition of the sludge: $\mathrm{Wt} \%$, mass percentage fraction; At $\%$, atomic percentage fraction determined by using the EDX method.

In Figure 2 the fact may be observed that there are important quantities of nutrients in the analyzed sludges, which recommends them as fertilizers for agricultural soils. 


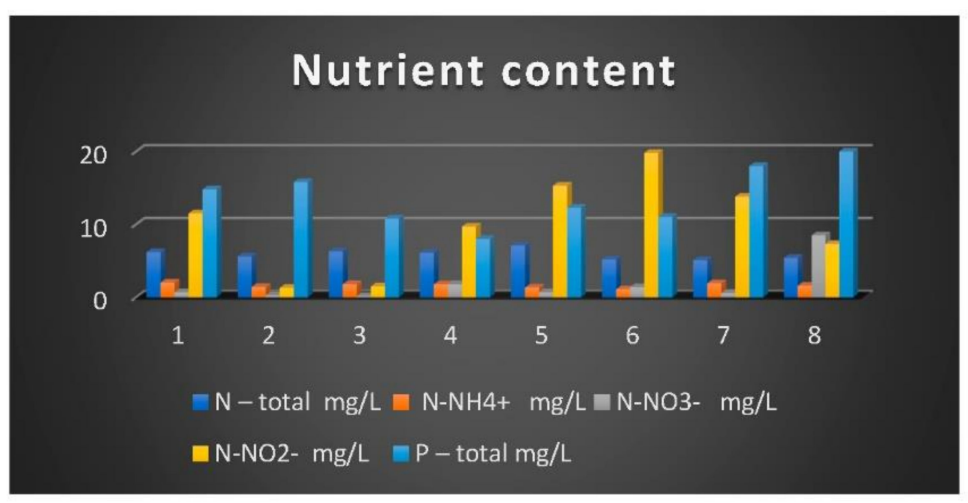

Figure 2. Nutrient content in the sewage sludge (quarterly average values).

Monitoring the composition of sewage sludges is important because, their content conditions their use. Taking into account the characteristics identified, sludges may be used in agriculture without the risk of heavy metals soil pollution (Figure 3). The sewage sludge from the WWTP in Galati has a low content of heavy metals, the determined values being much lower than the values specified by the regulations in force [38].

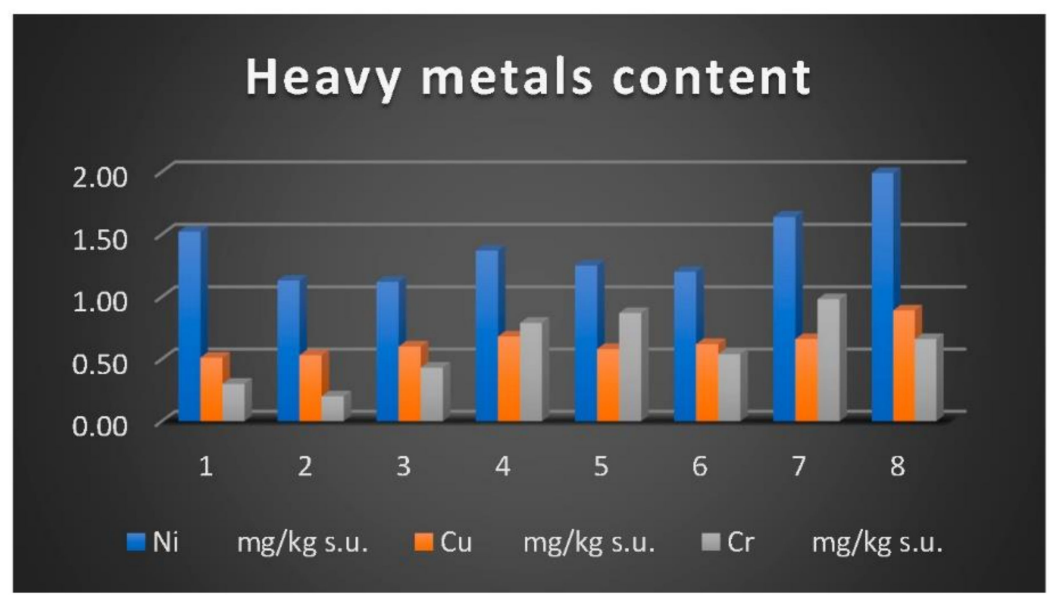

Figure 3. Heavy metals content in the sewage sludge (quarterly average values).

Moreover, analyzing the nutrient content, it has been found that sludges may be used as a substitute for chemical synthesis fertilizers, being much cheaper and less harmful to the environment.

Special attention was paid to analyzing the sludge $\mathrm{pH}$ values as these values may change when sludge is applied on agricultural land. Soil $\mathrm{pH}$ affects plant life and growth, as well as availability of soil nutrients for plants. The acidity or basicity of soils is extremely important because it affects the decomposition of minerals from the soil or from the sewage sludge with which the soil was amended in essential elements to be later used by plants. For this reason, it is recommended that the $\mathrm{pH}$ values of the sludge used should be higher than $6.5 \mathrm{pH}$ units, the mobility of the heavy metals reaching the plants which grow on these soils being greatly increased when the $\mathrm{pH}$ is acid. The $\mathrm{pH}$ of the analyzed sludges varied between 7.76-8.85 upH.

The studies carried out at the WWTP in Galati initaially covered 40 ha of agricultural lands on which the obtained sewage sludge was applied. Two main types of soils, whose average characteristics are presented in the Table 3, were identified: 
Table 3. Characteristics of the analyzed soils.

\begin{tabular}{cccc}
\hline No. & Characteristic & Soil Type 1 & Soil Type 2 \\
\hline 1 & Texture & U (sand clay) & S (sandy clay) \\
\hline 2 & Dense sand $(2.0-0.02 \mathrm{~mm})$ & $56.04 \%$ & $11.61 \%$ \\
\hline 3 & Fine sand $(0.2-0.02 \mathrm{~mm})$ & $34.48 \%$ & $63.80 \%$ \\
\hline 4 & Dust $(0.002-0.02 \mathrm{~mm})$ & $3.23 \%$ & $10.14 \%$ \\
\hline 5 & Argil $(<0.002 \mathrm{~mm})$ & $6.25 \%$ & $14.45 \%$ \\
\hline 6 & Apparent density $\left(\mathrm{g} \cdot \mathrm{cm}^{-3}\right)$ & 1.43 & 1.46 \\
\hline 7 & $\mathrm{pH}$ & 6.05 & 6.38 \\
\hline 8 & Humus & 0.57 & 0.15 \\
\hline 9 & Nitrogen index $(\mathrm{IN})$ & $0.78 \%$ & 11.8 \\
\hline 10 & $\mathrm{C}: \mathrm{N}$ & 13.2 & $0.008 \%$ \\
\hline 11 & $\mathrm{~N}_{\text {total }}$ & $0.040 \%$ & 40 \\
\hline 12 & $\mathrm{P}_{\text {mobil }}(\mathrm{ppm})$ & 43.2 & 104 \\
\hline 13 & $\mathrm{~K}_{\text {mobil }}(\mathrm{ppm})$ & 134 & 13.98 \\
\hline 14 & Exchange bases $(\mathrm{EB})$ & 7.84 & 90.66 \\
\hline 15 & Hydrolytic acidity $(\mathrm{HA})$ & 1.76 & \\
\hline & Degree of saturation in & 81.67 & bases (Vah) \\
\hline
\end{tabular}

Sewage sludge was applied twice a year on these lands, being applied each time approximately $1.5 \mathrm{t}$ of sludge/Ha and between $1.55-1.85 \mathrm{t}$ of calcareous amendments $/ \mathrm{ha}$. An improvement in the characteristics of these soils was observed (Table 4).

Table 4. Soil characteristics after the application of the sewage sludge and of calcareous amendments.

\begin{tabular}{cccc}
\hline No. & Characteristic & Soil Type 1 & Soil Type 2 \\
\hline 1 & $\mathrm{pH}$ & 6.67 & 6.83 \\
\hline 2 & Humus & 1.32 & 0.82 \\
\hline 3 & Nitrogen index (IN) & $0.89 \%$ & $0.43 \%$ \\
\hline 4 & $\mathrm{C}: \mathrm{N}$ & 13.1 & 13.1 \\
\hline 5 & $\mathrm{~N}_{\text {total }}$ & $0.062 \%$ & $0.029 \%$ \\
\hline 6 & $\mathrm{P}_{\text {mobil }}(\mathrm{ppm})$ & 57.2 & 51.3 \\
\hline 7 & $\mathrm{~K}_{\text {mobil }}(\mathrm{ppm})$ & 142 & 118 \\
\hline 8 & Exchange bases (EB) & 3.84 & 5.85 \\
\hline 9 & Hydrolytic acidity (HA) & 1.52 & 1.354 \\
\hline 10 & Degree of saturation in bases (Vah) & 78.35 & 83.65 \\
\hline
\end{tabular}

The principal characteristics of the all agricultural soils in Galati County were studied. The presence of certain substances (e.g., nitrogen or phosphorus compounds, Figure $4 b-d$ ) in agricultural soils should be taken into account because the limits are calculated by the accumulated quantities (nitrates present in the soil and nitrates present in the sludge). 

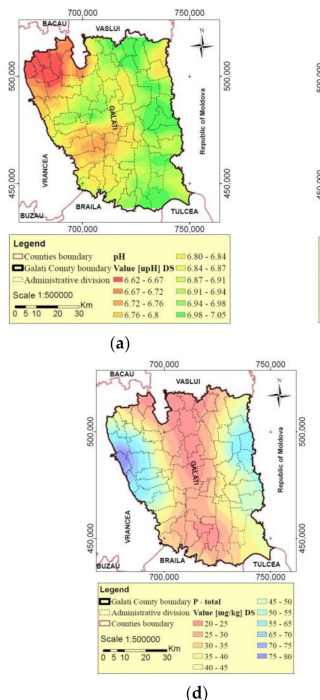

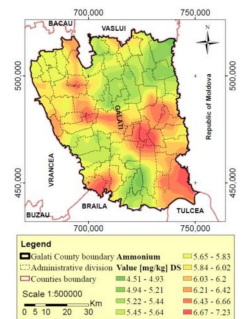

(b)

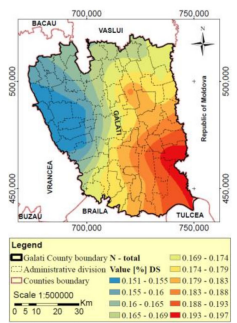

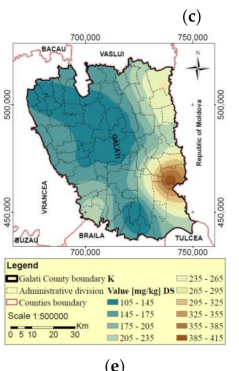

Figure 4. Dispersion model on the agricultural lands in Galati County: $\mathrm{pH}(\mathbf{a}) ; \mathrm{NH}_{4}{ }^{+}$(b); $\mathrm{N}-$ total (c); P-total (d); kalium (e).

The maximum acceptable content of heavy metals in the sewage sludge used on agricultural land is regulated by Directive 86/278 EEC and Order 344/2004 in national legislation $[4,38]$ so as to prevent harmful effects on soil, vegetation, animals, and population. The directive specifies the limit values for the concentration of heavy metals in the soil, and in the sludge and the maximum annual amount of heavy metals to which the soil may be exposed. According to national rules, the maximum concentrations allowed are: $500 \mathrm{mg}$ $\mathrm{Cr}^{3+} \cdot \mathrm{kg}^{-1}$ DS; $100 \mathrm{mg} \mathrm{Ni}^{2+} \cdot \mathrm{kg}^{-1}$ DS; $500 \mathrm{mg} \mathrm{Cu}^{2+} \cdot \mathrm{kg}^{-1}$ DS [38]. The quantities of metals from the studied agricultural soils are presented in Figure $5 \mathrm{a}-\mathrm{c}$. It is observed that they fall within the limits imposed by EU and national legislation.

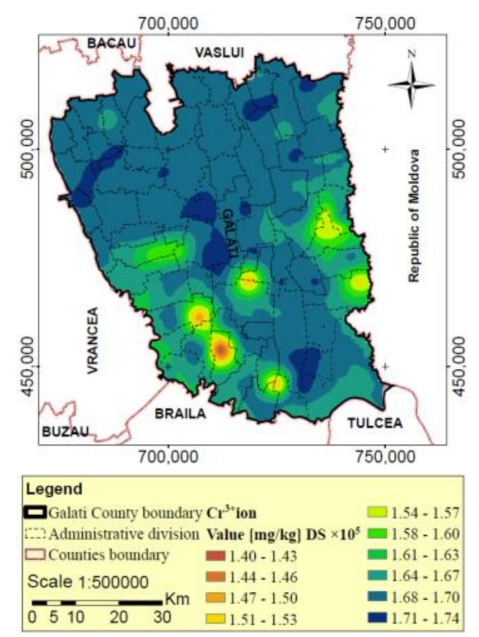

(a)

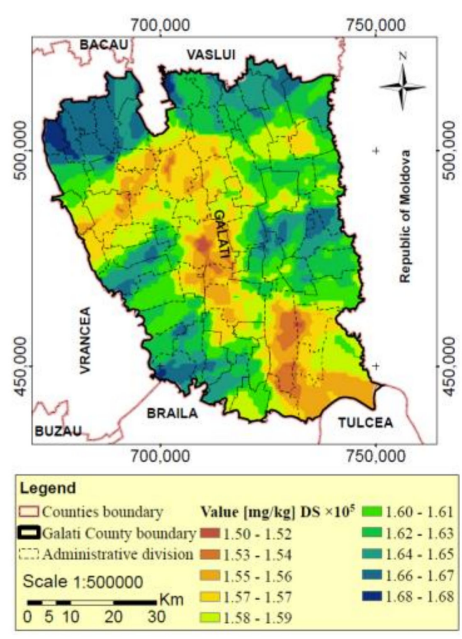

(b)

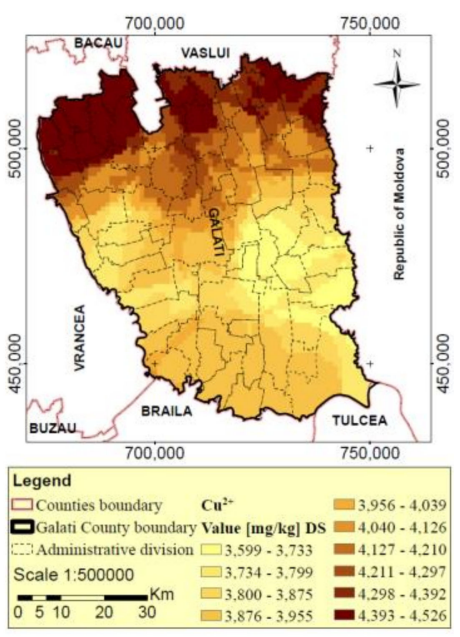

(c)

Figure 5. Dispersion model on the agricultural lands in Galati County: (a) $\mathrm{Cr}^{3+}$ ion; (b) $\mathrm{Ni}^{2+}$ ion; (c) $\mathrm{Cu}^{2+}$ ion.

Based on the data obtained from the agricultural land analysed, a statistical study was conducted to determine the correlations between different pollutants present in soils. The Principal Component Analysis (PCA) in Figure 6 shows the statistical relationship between the heavy metals present in agricultural soils. 


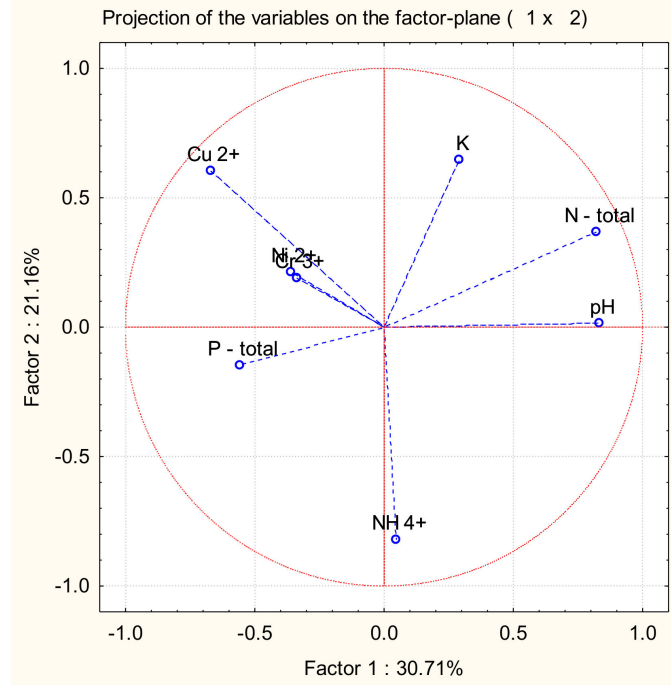

(a)

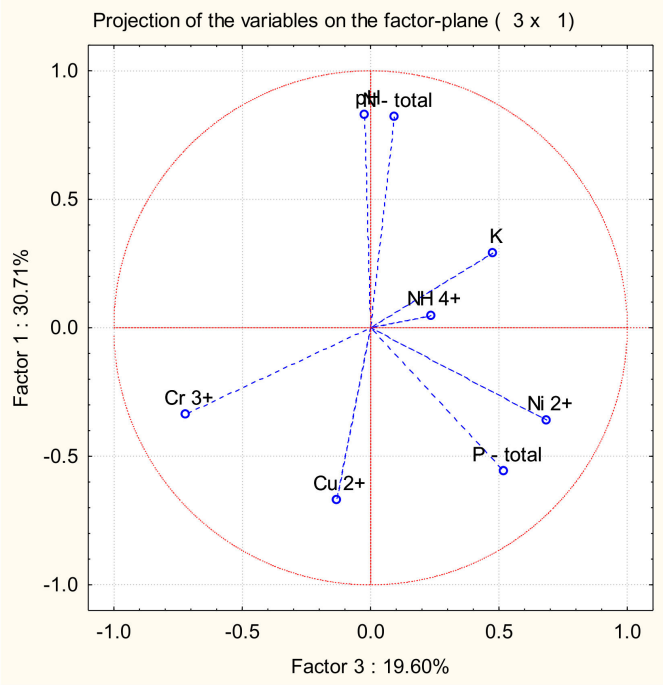

(b)

Figure 6. Non-supervised principal component analysis. (PCA) analysis representation of the relation between the metals and nutrients present in agricultural soils: (a) correlation F1-F2; (b) correlation F3-F1.

The matrix scatterplots illustrating the relationship between heavy metals may be seen in Figure 7, together with the corresponding Pearson correlation coefficient. Correlation coefficients are close to 1 only for $\mathrm{pH}$ related to $\mathrm{N}$-total, and for $\mathrm{N}$-total related with $\mathrm{K}$ (the green cells in Table 5). Table 5 shows that the best correlation.

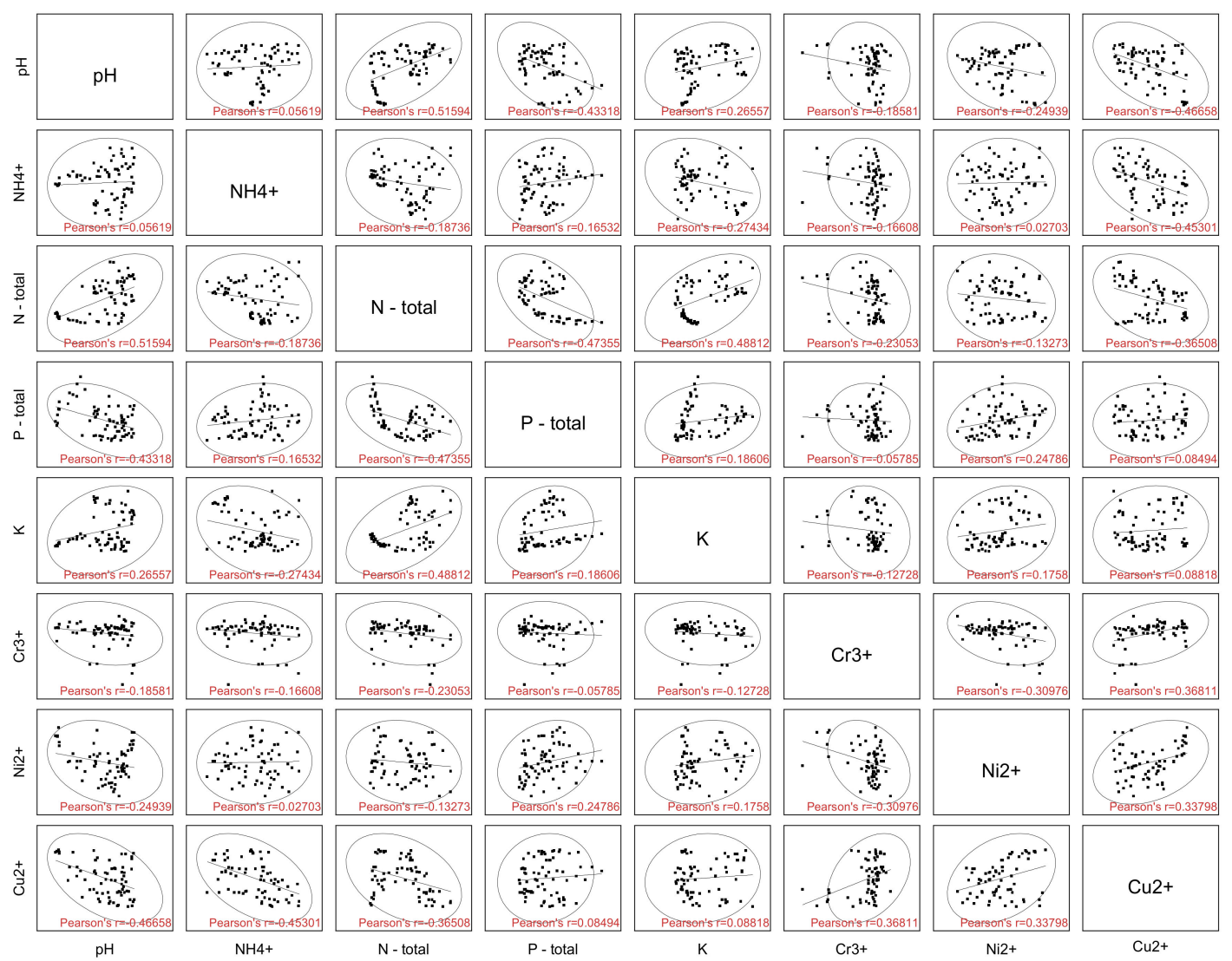

Figure 7. The matrix results of the statistical analysis which show the relationship between nutrients and heavy metals. 
Table 5. Results of the correlation between nutrients and heavy metals in agricultural soils.

\begin{tabular}{|c|c|c|c|c|c|c|c|c|}
\hline \multicolumn{9}{|c|}{ Pearson's Correlation } \\
\hline & $\mathrm{pH}$ & Ammonium & N-Total & P-Total & $\mathbf{K}$ & $\mathrm{Cr}^{3+}$ & $\mathrm{Ni}^{2+}$ & $\mathrm{Cu}$ \\
\hline $\mathrm{pH}$ & 1.000000 & 0.056191 & 0.515943 & -0.433178 & 0.265567 & -0.185806 & -0.249388 & -0.466579 \\
\hline Ammonium & & 1.000000 & -0.187359 & 0.165324 & -0.274344 & -0.166080 & 0.027026 & -0.453013 \\
\hline N-total & & & 1.000000 & -0.473553 & 0.488116 & -0.230531 & -0.132732 & -0.365083 \\
\hline P-total & & & & 1.000000 & 0.186062 & -0.057853 & 0.247860 & 0.084935 \\
\hline K & & & & & 1.000000 & -0.127279 & 0.175799 & 0.088183 \\
\hline $\mathrm{Cr}^{3+}$ & & & & & & 1.000000 & -0.309758 & 0.368113 \\
\hline $\mathrm{Ni}^{2+}$ & & & & & & & 1.000000 & 0.337982 \\
\hline $\mathrm{Cu}$ & & & & & & & & 1.000000 \\
\hline
\end{tabular}

\section{Discussion}

In the last 10 years, sewage treatment plants have been upgraded or built in most localities with more than 2000 inhabitants or clusters of localities have been set up and ascribed to a corresponding sewage treatment plant.

Wastewater treatment plants do not work at the full capacity they were designed for because the demographic forecast has been negative in recent years, and these plants were designed according to an estimate based on a positive forecast.

The use of sludge resulting from municipal wastewater treatment plants differs from one European country to another. Some countries, such as Belgium, Denmark, Spain, France, Ireland, and the UK, use over $50 \%$ of the collected sewage sludge directly on agricultural land, while others, such as: Greece, the Netherlands, Slovenia, Slovakia, etc., do not use sewage sludge in agriculture [61].

The composition of sewage sludge is conditioned by the quality of the waste water processed. The wastewater plants studied treat only domestic water and water discharged by consumers carrying out economic activities which do not involve high pollution levels. In most cases, industrial wastewater is pre-purged in the sewage treatment plants of the large industrial plants in the area, only afterwards being discharged in the municipal wastewater circuit. This explains the low levels of heavy metals found in the sludge analyzed, much lower than the limits imposed by the legislation in force. Another reason for the decrease of heavy metal load is the negative economic development in the studied area, as well as the fact that most of the industrial units found in the urban area before 1990 were moved outside this area.

Agriculture practiced on acidic, heavy soils, with a chemical composition unfavorable to plants, drastically reduces the profitability of farmers, due to the sharp increase in production cost to be covered for pedo-improvement, to the mandatory sequence to maintain some variability of the cultivated plants and, implicitly, to the level of the crops obtained.

The elimination of environmental risks, as well as the potential impact for human and animal health in the use of sludge from treatment plants, requires thorough studies in various stations associated with the chemical content of these sludges [62]. The present article aims to broaden the area of knowledge in this field. This is the reason why solutions are sought to increase the $\mathrm{pH}$ of sewage sludge so that the $\mathrm{pH}$ of soils does not decrease when sewage sludge is used on agricultural land. Sludge from urban wastewater may be used with high efficiency as an organic soil fertilizer. The legislation in the EC and Romania specifies that the administration may be performed only on low acidic to neutral soils, respectively, which have a $\mathrm{pH}$ higher than 6.0.

Strict control of pollutants dispersed on agricultural land is as important as avoiding acidification of agricultural soils [63]. In the practical research carried out in this study, the determination of the existing concentrations in the soil for the monitored pollutants was performed simultaneously with the $\mathrm{pH}$ determination of the soils on which the sludge dispersion was to be made. At the same time, methods for correcting the $\mathrm{pH}$ were considered where appropriate. 
In order to prevent soil acidification as a result of these transformations, we suggest that sludge treatment should be distributed simultaneously with chemicals on arable land in agriculture so as to have the effect of acid-base buffer systems. Acid-base buffer systems stabilize the $\mathrm{pH}$ of soils within the limits of the $\mathrm{pKa}$ acidic component ( $\mathrm{pKa}$ is the negative $\log$ of the acidity constant of the buffer system acidic component) [64]. Since the $\mathrm{pH}$ of soils in agricultural areas in Galati County is $6.5 \pm 0.5 \mathrm{pH}$ units, the pKa of the acidic component of the buffer system must be in the same range. In this case, i.e., of the sludges administered on arable lands, we considered $\mathrm{CaCO}_{3}-\mathrm{Ca}\left(\mathrm{HCO}_{3}\right)_{2}$ as the buffer system whose acid component has $\mathrm{pKa}=7.48$.

The procedure for obtaining the buffer system is relatively simple and does not imply very high costs. In this sense, raw materials, found in abundance in nature in the form of minerals such as calcite $\left(\mathrm{CaCO}_{3}\right)$ or dolomite $\left(\mathrm{CaCO}_{3} \mathrm{MgCO}_{3}\right)$, may be used. These minerals are found in various ores in our country located in the limestone mountains and are purchased in industrial quantities by Arcellor Mitall steel plant in Galati (which uses them as a flux in the production of cast iron in the blast furnace).

The $\mathrm{CaCO}_{3}-\mathrm{Ca}\left(\mathrm{HCO}_{3}\right)_{2}$ buffer system is made in time after the administration, in the soil, of the sludges from the urban wastewater treatment plants added with calcite or dolomite granules according to the chemical reaction below:

$$
2 \mathrm{CaCO}_{3}+2 \mathrm{H}^{+}=\mathrm{Ca}\left(\mathrm{HCO}_{3}\right)_{2}+\mathrm{Ca}^{2+}
$$

In a first stage, the acidic substances formed, brought in contact with the neutral carbonate from calcite or dolomite, will generate the acidic component of the buffer system represented by the acid carbonate.

When the pollutants are controlled strictly and an acceptable $\mathrm{pH}$ is maintained at the soil level, sludges may be combined with other types of organic waste such as organic composts [65]. In the applications on the lands analysed in the present study, the fact was considered that the sludge should be distributed before its drying in order to add a moisture contribution in the treated soils.

The buffer system thus made the remains functional in the following stages when a new administration of sludge from the treatment plants was possible without adding a new amount of calcite or dolomite. This procedure was validated after a careful monitoring regarding the buffering capacity of the system thus formed.

The use of sewage sludge reduces the amount of chemical fertilizers which should be applied in order to ensure plant growth and also supports the elimination of the problems created by the accumulation of increasing amounts of sludge. According to the fertilization plan established with WWTP Galati and the owner of the agricultural lands, they were applied approximately $1.5 \mathrm{t}$ of sewage sludge/ha and between 1.55-1.85 $\mathrm{t}$ of calcareous amendments/ha twice a year, depending on the agricultural culture that was to be cultivated on the respective lands. Considering that the Romanian legislation does not allow the application of sewage sludge for values lower than the soil $\mathrm{pH}$, the calcareous amendments were added to raise the $\mathrm{pH}$ of the soils to values higher than 6.5.

Studies showed that there was an improvement in soil quality, which led to the conclusion that sewage sludge should be reapplied on soils in order to maintain their characteristics acquired after the first sewage sludge applications (Table 4). There is no danger of metal pollution when using sewage sludge on soil, because, taking into account the synergistic and cumulative effects, the concentrations of these elements are much lower than the maximum values allowed by agricultural soil legislation (Figures 1-3).

Based on the data obtained from the agricultural land analysed, a statistical study was conducted to determine the correlations between different pollutants present in soils. The Principal Component Analysis (PCA) in Figure 6 shows the statistical relationship between the heavy metals present in agricultural soils. By linearly compressing the whole set of main input data, the uncorrelated variables in the main data set may be identified and analysed more easily in the reduced data set. In this case, the fact could be observed that the $\mathrm{pH}$ and $\mathrm{N}$-total in correlation F1-F2 have the same behaviour. This is also applicable in 
the case of correlation F3-F1. The PCA analysis shows a small angle formed both between $\mathrm{K}$ and $\mathrm{N}$ - total and between $\mathrm{N}$-total and $\mathrm{pH}$. This angle is a clear indication that these parameters are suitable for a classification model. The relationship between heavy metals may be seen in Figure 7 (the matrix scatterplots) together with the corresponding Pearson correlation coefficient. Correlation coefficients are close to 1 only for $\mathrm{pH}$ related to $\mathrm{N}$-total, and for $\mathrm{N}$-total related with $\mathrm{K}$ (the green cells in Table 2). The other statistically analyzed heavy metals have a diffuse data dispersion in all matrix cases.

The observations regarding the practical research in this article pointed out the fact that industrial activities with potential for municipal water pollution and sewage sludge decreased enormously in the studied urban regions, as well as in other urban regions throughout Romania (the industrial activity in the municipal wastewater collecting area decreased by over $90 \%$ in the southeast region of Romania, which led to a drastic decrease in the level of industrial pollutants present in the collected sewage sludge).

The use of sludge for agricultural soils has a clearly positive influence on rhizosphere, soil fertility, on the increase of microbial biomass and of enzymatic activity even when significant quantities of sludge are repeatedly deposited on such soils [66]. In this article, the fact was found that the interaction of agricultural soils with sewage sludge did not cause degradation or changes in soil salinity or $\mathrm{pH}$ which could adversely affect its texture and/or fertility.

The characterization of sewage sludge is extremely important in order to determine how the quantities of sludge resulting from the treatment process may be reduced or even eliminated altogether. The use of sewage sludge in agriculture, before its disposal or application on agricultural land, implies a risk of accumulation of toxic elements in the soil.

Based on the analysis of the experimental results, it has been found that the values of the physico-chemical parameters analyzed fall within the limits imposed by the legislation in force and that these sludges are not harmful to the environment. The use of sludge in agriculture has alternatives related to their heat treatment. It has been found that alternatives are particularly difficult to implement on a large scale [66] due to the increasing quantities of sewage sludge collected and to the very high operating costs for the installations, including the deployment of incinerated gases. The present study has been adapted to the investment possibilities in Romania and in the countries of Central and Eastern Europe, regions which are unlikely to have financial resources for incineration or for pyrolysis installations causing a less significant pollution of the atmosphere.

\section{Conclusions}

This article envisages the use of a method of sludge recovery resulting from municipal wastewater treatment plants. The integrated approach including $\mathrm{pH}$ control and maintenance, as well as the moisture input, leads to scientific and practical conclusions which may be extended to much larger regions.

1. The use of sewage sludge reduces the amount of chemical fertilizers and also supports the elimination of the problems created by the accumulation of increasing amounts of sludge.

2. There is no danger of heavy metals pollution when using sewage sludge on soil.

3. The $\mathrm{pH}$ of the sewage sludge applied on soil must be higher than 6.0 in order to avoid the increased mobility of heavy metals in the sludge, which would lead to the contamination of plants with heavy metals.

4. The analyzed sludges contain significant amounts of nutrients, which give them the properties of organic fertilizers. They also contribute to maintaining and improving the texture of degraded soils.

5. The characterization of sewage sludge is extremely important in order to deter-mine how the quantities of sludge resulting from the treatment process may be reduced or even eliminated altogether. 
6. It is necessary to continuously monitor the physical, chemical and biological characteristics of the sludge including the presence of certain chemical species which must not exceed, cumulatively, the acceptable limits.

Author Contributions: Conceptualization: C.I. and P.-L.G.; data curation: C.I., M.A., A.R., and G.C.; formal analysis: M.A., A.R., and L.-I.C.; funding acquisition: C.I., P.-L.G., and L.-I.C.; investigation: M.T., M.A., A.R., and G.C.; methodology: C.I. and P.-L.G.; writing-original draft preparation: C.I., P.-L.G., and M.A.; writing - review and editing: C.I. and L.-I.C. All authors have read and agreed to the published version of the manuscript.

Funding: This work was supported by the applied research project 731/2017, “Technologies for the recovery of sludge from urban wastewater treatment plants and of waste from landfills".

Institutional Review Board Statement: Not applicable.

Informed Consent Statement: Not applicable.

Data Availability Statement: Not applicable.

Acknowledgments: The linguistic review of the present article was made by Antoanela Marta Mardar, member of the Research Center "Interface Research of the Original and Translated Text. Cognitive and Communicative Dimensions of the Message", Faculty of Letters, "Dunărea de Jos" University of Galati, Romania. Project financed by Lucian Blaga University of Sibiu and Hasso Plattner Foundation, research grants LBUS-IRG-2020-06.

Conflicts of Interest: The authors declare no conflict of interest.

\section{References}

1. Iticescu, C.; Georgescu, L.P.; Murarescu, M. Use of Sewage Sludge; Galati University Press: Galati, Romania, 2015; ISBN 978-606-696-031-1.

2. Directive 2000/60/EC of the European Parliament and of the Council of 23 October 2000 Establishing a Framework for Community Action in the Field of Water Policy. Off. J. Eur. Union 2000, 327, 1-73.

3. Council Directive 91/271/EEC of 21 May 1991 Concerning Urban Waste-Water Treatment. Off. J. Eur. Union 1991, 135, 40-52.

4. Council Directive 86/278/CEE of 12 June 1986 On the Protection of the Environment, Especially of the Soil, When Sewage Sludge Is Used in Agriculture, Elaboration of the National Sewage Sludge Management Policy. Off. J. Eur. Union 1986, 181, 6-12.

5. Fytili, D.; Zabaniotou, A. Utilization of Sewage Sludge in EU Application of Old and New Methods-A Review. Renew. Sustain. Energy Rev. 2008, 12, 116-140. [CrossRef]

6. Metcalf \& Eddy, Inc. Wastewater Engineering: Treatment Disposal Reuse, 3rd ed.; McGraw-Hill: New York, NY, USA, 1991.

7. Rizzardini, C.B.; Goi, D. Sustainability of Domestic Sewage Sludge Disposal. Sustainability 2014, 6, 2424-2434. [CrossRef]

8. Przydatek, G.; Wota, A.K. Analysis of the Comprehensive Management of Sewage Sludge in Poland. J. Mater. Cycles Waste Manag. 2020, 22, 80-88. [CrossRef]

9. Liu, H.-T. Achilles Heel of Environmental Risk from Recycling of Sludge to Soil as Amendment: A Summary in Recent Ten Years (2007-2016). Waste Manag. 2016, 56, 575-583. [CrossRef] [PubMed]

10. Duan, B.; Zhang, W.; Zheng, H.; Wu, C.; Zhang, Q.; Bu, Y. Disposal Situation of Sewage Sludge from Municipal Wastewater Treatment Plants (WWTPs) and Assessment of the Ecological Risk of Heavy Metals for Its Land Use in Shanxi, China. Int. J. Environ. Res. Public Health 2017, 14, 823. [CrossRef] [PubMed]

11. Melo, W.; Delarica, D.; Guedes, A.; Lavezzo, L.; Donha, R.; de Araújo, A.; de Melo, G.; Macedo, F. Ten Years of Application of Sewage Sludge on Tropical Soil. A Balance Sheet on Agricultural Crops and Environmental Quality. Sci. Total Environ. 2018, 643, 1493-1501. [CrossRef] [PubMed]

12. Gherghel, A.; Teodosiu, C.; De Gisi, S. A Review on Wastewater Sludge Valorisation and Its Challenges in the Context of Circular Economy. J. Clean. Prod. 2019, 228, 244-263. [CrossRef]

13. Pradel, M. Survey Data of Sewage Sludge Treatment and Disposal Routes Originated from Activated Sludge Water Treatment in France. Data Brief 2019, 26. [CrossRef] [PubMed]

14. Turek, A.; Wieczorek, K.; Wolf, W.M. Digestion Procedure and Determination of Heavy Metals in Sewage Sludge-An Analytical Problem. Sustainability 2019, 11, 1753. [CrossRef]

15. Nascimento, A.L.; de Souza, A.J.; Oliveira, F.C.; Coscione, A.R.; Viana, D.G.; Regitano, J.B. Chemical Attributes of Sewage Sludges: Relationships to Sources and Treatments, and Implications for Sludge Usage in Agriculture. J. Clean. Prod. 2020, 258. [CrossRef]

16. Kelessidis, A.; Stasinakis, A.S. Comparative Study of the Methods Used for Treatment and Final Disposal of Sewage Sludge in European Countries. Waste Manag. 2012, 32, 1186-1195. [CrossRef] [PubMed]

17. Report from the Commission to the European Parliament and the Council on the Implementation of the Water Framework Directive (2000/60/EC), River Basin Management Plans.; Publications Office of the EU: Brussels, Belgium, 2012.

18. Iticescu, C.; Georgescu, L.P.; Gurau, G.; Murarescu, M.; Dima, D.; Murariu, G.; Gheorghies, C. Methods to Reduce Environmental Impact of Municipal Waste Water Sewage Sludge. Environ. Eng. Manag. J. 2015, 14, 2457-2463. [CrossRef] 
19. Murariu, G.; Iticescu, C.; Georgescu, L.; Mocanu, I.; Topa, C.; Dobre, M. Optimization of Urban Selective Waste Collection Activity: Galati City Case Study. Environ. Eng. Manag. J. 2015, 14, 2471-2492. [CrossRef]

20. Spinosa, L.; Ayol, A.; Baudez, J.-C.; Canziani, R.; Jenicek, P.; Leonard, A.; Rulkens, W.; Xu, G.; van Dijk, L. Sustainable and Innovative Solutions for Sewage Sludge Management. Water 2011, 3, 702-717. [CrossRef]

21. Korentajer, L. A Review of the Agricultural Use of Sewage Sludge: Benefits and Potential Hazards. Water SA 1991, 17, 189-196.

22. MO 344/708 of 16 August 2004, For the Approval of the Technical Norms on the Protection of the Environment and in Particular of the Soils, when Using Sewage Sludge in Agriculture. The Official Monitor; no. 959; 19 October 2004. (In Romanian)

23. Tsadilas, C.; Samaras, V.; Evangelou, E.; Shaheen, S.M. Influence of Fly Ash and Sewage Sludge Application on Wheat Biomass Production, Nutrients Availability, and Soil Properties. Int. J. Coal Sci. Technol. 2014, 1, 221-226. [CrossRef]

24. Guerra-Rodríguez, S.; Oulego, P.; Rodríguez, E.; Singh, D.N.; Rodríguez-Chueca, J. Towards the Implementation of Circular Economy in the Wastewater Sector: Challenges and Opportunities. Water 2020, 12, 1431. [CrossRef]

25. Iticescu, C.; Georgescu, L.P.; Murariu, G.; Circiumaru, A.; Timofti, M. The Characteristics of Sewage Sludge Used on Agricultural Lands. Aip Conf. Proc. 2018, 2022, 020001. [CrossRef]

26. Curci, M.; Lavecchia, A.; Cucci, G.; Lacolla, G.; De Corato, U.; Crecchio, C. Short-Term Effects of Sewage Sludge Compost Amendment on Semiarid Soil. Soil Syst. 2020, 4, 48. [CrossRef]

27. Burducea, M.; Lobiuc, A.; Asandulesa, M.; Zaltariov, M.-F.; Burducea, I.; Popescu, S.M.; Zheljazkov, V.D. Effects of Sewage Sludge Amendments on the Growth and Physiology of Sweet Basil. Agronomy 2019, 9, 548. [CrossRef]

28. Urra, J.; Alkorta, I.; Garbisu, C. Potential Benefits and Risks for Soil Health Derived From the Use of Organic Amendments in Agriculture. Agronomy 2019, 9, 542. [CrossRef]

29. Ondreičková, K.; Gubišová, M.; Piliarová, M.; Horník, M.; Matušinský, P.; Gubiš, J.; Klčová, L.; Hudcovicová, M.; Kraic, J. Responses of Rhizosphere Fungal Communities to the Sewage Sludge Application into the Soil. Microorganisms 2019, 7, 505. [CrossRef] [PubMed]

30. Rosiek, K. Directions and Challenges in the Management of Municipal Sewage Sludge in Poland in the Context of the Circular Economy. Sustainability 2020, 12, 3686. [CrossRef]

31. Lamastra, L.; Suciu, N.A.; Trevisan, M. Sewage Sludge for Sustainable Agriculture: Contaminants' Contents and Potential Use as Fertilizer. Chem. Biol. Technol. Agric. 2018, 5, 10. [CrossRef]

32. National Waste Management Strategy 2014-2020 (HG 870/2013). Available online: http:/ /www.mmediu.ro/img/attachment/ 37/strategii-planuri-studii-54786031cda10.pdf (accessed on 12 December 2020).

33. National Waste Management Plan (H.G. No. 1470/09.09.2004). Available online: http://www.mmediu.ro/beta/wp-content/ uploads/2012/05/2012-05-17_hg_1470_2004.pdf (accessed on 12 December 2020).

34. Singh, R.P.; Agrawal, M. Variations in Heavy Metal Accumulation, Growth and Yield of Rice Plants Grown at Different Sewage Sludge Amendment Rates. Ecotoxicol. Environ. Saf. 2010, 73, 632-641. [CrossRef]

35. De Figueiredo, C.C.; Coser, T.R.; Moreira, T.N.; Leão, T.P.; Vale, A.T.D.; Paz-Ferreiro, J. Carbon Mineralization in a Soil Amended with Sewage Sludge-Derived Biochar. Appl. Sci. 2019, 9, 4481. [CrossRef]

36. Belhaj, D.; Elloumi, N.; Jerbi, B.; Zouari, M.; Abdallah, F.B.; Ayadi, H.; Kallel, M. Effects of Sewage Sludge Fertilizer on Heavy Metal Accumulation and Consequent Responses of Sunflower (Helianthus annuus). Environ. Sci. Pollut. Res. 2016, 23, 20168-20177. [CrossRef]

37. Eid, E.M.; Alrumman, S.A.; El-Bebany, A.F.; Hesham, A.E.-L.; Taher, M.A.; Fawy, K.F. The Effects of Different Sewage Sludge Amendment Rates on the Heavy Metal Bioaccumulation, Growth and Biomass of Cucumbers (Cucumis sativus L.). Environ. Sci Pollut. Res. 2017, 24, 16371-16382. [CrossRef] [PubMed]

38. Order 344/2004 for the Approval of the Technical Norms on the Protection of the Environment and in Particular of the Soils, when the Sewage Sludges Are Used in Agriculture. Available online: http://www.mmediu.ro/beta/wp-content/uploads/2012 /06/2012-06-01_OM_344_2004.pdf (accesed on 21 January 2021).

39. Institute for Standardization of Serbia. SR EN 12176:2000—Characterization of Sludge. Determination of pH Value; ISS: Belgrade, Serbia, 2000.

40. Institute for Standardization of Serbia. SR ISO 11261:2000_Determination of Nitrogen Content; ISS: Belgrade, Serbia, 2000.

41. Institute for Standardization of Serbia. SR ISO 7150-1:2001-Water Quality. Determination of Ammonium Content. Part 1: Manual Spectrometric Method; ISS: Belgrade, Serbia, 2001.

42. Romanian Standards Association. STAS 12205-84-Sludges from Surface Water Treatment and Wastewater Treatment. Determination of Phosphorus Content; ASRO: Bucharest, Romania, 1984.

43. Institute for Standardization of Serbia. SR 13117/92 — Sludges from Surface Water Treatment and Wastewater Treatment. Determination of Chromium Content; ISS: Belgrade, Serbia, 1992.

44. Institute for Standardization of Serbia. SR 13179/93 - Sludges from Surface Water Treatment and Wastewater Treatment. Determination of Copper Content; ISS: Belgrade, Serbia, 1992.

45. Institute for Standardization of Serbia. SR EN 16192:2012—Sludges from Surface Water Treatment and Wastewater Treatment. Determination of Ni2+ Content; ISS: Belgrade, Serbia, 2012.

46. Romanian Standards Association. Soils. Determination of the Granulometric Composition—STAS 7184/10-79; ASRO: Bucharest, Romania, 1979.

47. International Standard. ISO 11272:1998, Soil Quality—Determination of Bulk Density; ISO: Geneva, Switzerland, 1998. 
48. Romanian Standards Association. Soils. Determination of Humus Content-STAS 7184-21-82; ASRO: Bucharest, Romania, 1982.

49. Lacatusu, R. Mineralogy and Soil Chemistry; Alexandru Ioan Cuza University: Iasi, Romania, 2000.

50. Soil Survey Staff. Soil Survey Laboratory Information Manual; Soil Survey Investigations Report No. 45, Version 2.0; Burt, R., Ed.; U.S. Department of Agriculture, Natural Resources Conservation Service: Washington, DC, USA, 2011; 142p.

51. Romanian Standards Association. Soils. Determination of Nitrogen Content-STAS 7184/2-85; ASRO: Bucharest, Romania, 1985.

52. Romanian Standards Association. Soils. Determination of Extractable Phosphorus in Ammonium Acetate-Lactate-STAS 7184/19-82; ASRO: Bucharest, Romania, 1982.

53. Institute for Standardization of Serbia. Soil Quality. Determination of Potential Cation Exchange Capacity and Exchangeable Cations-SR ISO 13536:2001; ISS: Belgrade, Serbia, 2001.

54. Institute for Standardization of Serbia. Soil Quality. Determining the Effective Cation Exchange Capacity and the Degree of Saturation in Bases-SR EN ISO 11260:2018; ISS: Belgrade, Serbia, 2018.

55. Institute for Standardization of Serbia. Test Method for Determining the Degree of Soil Acidity —SR EN 16502:2015; ISS: Belgrade, Serbia, 2015.

56. Zhiyuan, W.; Dengfeng, W.; Huiping, Z.; Zhiping, Q.I. Assessment of soil heavy metal pollution with Principal component analysis and Geoaccumlation index. Procedia Environ. Sci. 2011, 10, 1946-1952. [CrossRef]

57. Doyi, I.; Essumang, D.; Gbeddy, G.; Dampare, S.; Kumassah, E.; Saka, D. Spatial distribution, accumulation and human health risk assessment of heavy metals in soil and groundwater of the Tano Basin, Ghana. Ecotoxicol. Environ. Saf. 2018, 165, 540-546. [CrossRef]

58. Shan, Y.; Tysklind, M.; Hao, F.; Ouyang, W.; Chen, S.; Lin, C. Identification of sources of heavy metals in agricultural soils using multivariate analysis and GIS. J. Soils Sediments 2013, 13, 720-729. [CrossRef]

59. Qishlaqi, A.; Moore, F. Statistical Analysis of Accumulation and Sources of Heavy Metals Occurrence in Agricultural Soils of Khoshk River Banks, Shiraz, Iran. Am. J. Agric. Environ. Sci. 2007, 2, 565-573.

60. Kacprzak, M.; Neczaj, E.; Fijałkowski, K.; Grobelak, A.; Grosser, A.; Worwag, M.; Rorat, A.; Bratebbo, H.; Almas, A.; Singh, B.R. Sewage sludge disposal strategies for sustainable development. Environ. Res. 2017, 156, 39-46. [CrossRef]

61. Bondarczuk, K.; Markowicz, A.; Piotrowska-Seget, Z. The urgent need for risk assessment on the antibiotic resistance spread via sewage sludge land application. Environ. Int. 2016, 87, 49-55. [CrossRef] [PubMed]

62. Li, Y.; Sun, J.; Tian, D.; Wang, J.; Ha, D.; Qu, Y.; Jing, G.; Niu, S. Soil acid cations induced reduction in soil respiration under nitrogen enrichment and soil acidification. Sci. Total Environ. 2018, 615, 1535-1546. [CrossRef]

63. Dulman, V. Basics of Analytical Chemistry; Editura Pim: Iasi, Romania, 2002.

64. Alvarenga, P.; Farto, M.; Mourinha, C.; Palma, P. Beneficial Use of Dewatered and Composted Sewage Sludge as Soil Amendments: Behaviour of Metals in Soils and Their Uptake by Plants. Waste Biomass Valoriz. 2016, 7, 1189-1201. [CrossRef]

65. Hamdi, H.; Hechmi, S.; Khelil, M.N.; Zoghlami, I.R.; Benzarti, S.; Tlili, S.M.; Hassen, A.; Jedidi, N. Repetitive land application of urban sewage sludge: Effect of amendment rates and soil texture on fertility and degradation parameters. Catena 2019, 172, 11-20. [CrossRef]

66. Raheem, A.; Sikarwar, V.S.; He, J.; Dastyar, W.; Dionysiou, D.; Zhao, M. Opportunities and challenges in sustainable treatment and resource reuse of sewage sludge: A review. Chem. Eng. J. 2018, 337, 616-641. [CrossRef] 